Journal of Anatolian Environmental and Animal Sciences

(Anadolu Çevre ve Hayvancılık Bilimleri Dergisi)

DOI: https://doi.org/10.35229/jaes.750507

\title{
Estimation of Chemical Composition, In Vitro Digestibility and Metabolic Energy of Peanut Straw and Waste of Peanut Oil Factory [*]
}

\author{
Nurcan ÇETINKAYA ${ }^{\mathbf{1}} \quad$ Funda ERDEM $^{2 *} \quad$ Habip MURUZ $^{\mathbf{1}}$ \\ ${ }^{1}$ Ondokuz Mayls University, Faculty of Veterinary Medicine, Department of Animal Nutrition and Nutritional Diseases, Samsun,Turkey. \\ ${ }^{2}$ Ministry of Health, Public Health Laboratory, Department of Moleculer Microbiology, Samsun, Turkey.
}

How to cite: Çetinkaya, N., Erdem, F. \& Habip M. (2020). Estimation of Chemical Composition, In Vitro Digestibility and Metabolic Energy of Peanut Straw and Waste of Peanut Oil Factory. J. Anatolian Env. and Anim. Sciences, 5(3), 335-339.

Atıf yapmak için: Çetinkaya, N., Erdem, F. \& Habip M. (2020). Yerfıstığı Samanı ve Yerfıstı̆̆ı Yağ Fabrikası Atıklarının Kimyasal Kompozisyonu, In Vitro Sindirilebilirlik ve Metabolik Enerjisinin Belirlenmesi. Anadolu Çev. ve Hay. Dergisi, 5(3), 335-339.

*Corresponding author's: Funda ERDEM Ministry of Health, Public Health Laboratory, Department of Moleculer Microbiology, Samsun, Turkey.

凶: fundaerdemtr@gmail.com

Mobile telephone : +90 (541) 4543732
Abstract: The objective of this study was to evaluate chemical composition, organic matter digestibility (OMD) and metabolic energy (ME) values of the most cultivated Osmaniye Virginia peanut variety straw, and peanut seed residue and peanut meal which are wastes of peanut oil factory in Osmaniye- Turkey for ruminant nutrition. The levels of OMD and ME of feed samples were determined by in vitro gas production method. The mean organic matter (OM), crude protein $(\mathrm{CP})$, ether extract (EE), neutral detergent fiber (NDF), acid detergent fiber (ADF) and acid detergent lignin (ADL) levels of peanut straw, peanut seed residue and peanut meal were estimated as following $92.10,89.22$ and $93.70 \% ; 10.22,23.16$ and $41.25 \% ; 2.30,8.21$ and $6.45 \%$; $51.14,35.27$ and $28.44 \% ; 41.72,18.83$ and $13.20 \% ; 8.77,6.17$ and $4.71 \%$ respectively. OMD\%, MEomD and MEGP MJ/kgDM values of peanut straw, peanut seed residue and peanut meal determined as $56.12,61.38$ and $71.80 ; 8.98,9.82$ and $11.49 ; 7.69,7.03$ and 8.10 respectively. The obtained results show that cultivated Osmaniye Virginia peanut variety straw, peanut seed residue and peanut meal are an excellent nutrients source to meet nutritional requirements of ruminant animals.

Keywords: In vitro digestibility, metabolic energy, nutrients, peanut straw, peanut meal, peanut seed residue.

\section{Yerfıstı̆̆ı Samanı ve Yerfıstığı Yağ Fabrikası Atıklarının Kimyasal Kompozisyonu, In Vitro Sindirilebilirlik ve Metabolik Enerjisinin Belirlenmesi}

*Sorumlu yazar:

Funda ERDEM

Sağlık Bakanlığı, Halk Sağlığı Laboratuvarı,

Moleküler Mikrobiyoloji Anabilim Dalı,

Samsun, Türkiye.

$\bowtie$ : fundaerdemtr@gmail.com

Mobile telephone : +90 (541) 4543732
Öz: Bu çalışmanın amacı Osmaniye-Türkiye'de yetiştirilen en iyi kültürü yapılmış Osmaniye Virjinya yer fistığı çeşidinin samanı ve yerfıstığı yağ fabrikası atıklarından elek altı tohum ve fistık küspesinin kimyasal kompozisyonu, organik madde sindirilebilirliği (OMS) ve metabolik enerji (ME) değerlerinin ruminant besleme için belirlenmesidir. Yem örneklerinin OMS ve ME değerleri in vitro gaz üretim metodu ile belirlendi. Yerfistığı samanı, elek altı ve fistık küspesinin ortalama organik madde (OM), ham protein (HP), ham yağ (HY), nötral deterjan fiber (NDF), asit deterjan fiber (ADF) ve asit deterjan lignin (ADL) seviyeleri sirasiyla \% 92.10, 89.22 ve 93.70; \% 10.22, 23.16 ve 41.25; \% 2.30, 8.21 ve $6.45 ; \% 51.14,35.27$ ve \% 28.44; \% 41.72, 18.83 ve $13.20 ; \% 8.77,6.17$ ve \% 4.71 olarak hesapland1. Yerfistığ 1 saman1, elek altı tohum ve küspenin

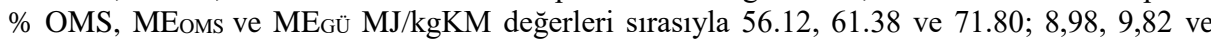
11,$49 ; 7.69,7.03$ ve 8.10 olarak belirlendi. Bulunan sonuçlar, yetiştirilen Osmaniye Virginia fistık çeşidinin samanı, elek altı tohumu ve küspesinin rminant hayvanların beslenme ihtiyaçlarını karşılamak için çok iyi bir besin maddeleri kaynağı olduğunu göstermektedir.

Anahtar kelimeler: Besin maddeleri, In vitro sindirilebilirlik, metabolik enerji, yerfistığı samanı,

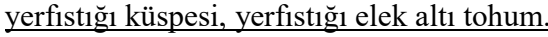




\section{INTRODUCTION}

Peanut is an essential crop in tropics and subtropical regions worldwide. The largest producers of peanuts are China, India, the USA, and certain African countries (Stalker \& Wilson, 2015). Peanuts (Arachis hypogaea) are mostly produced in Adana and Osmaniye province of Turkey, and total peanut production was 424.000 tonnes in the year 2019 (TUIK, 2019). Consequently, the peanut straw production corresponded nearly 424.000 tonnes per year.

Peanuts (Arachis hypogaea) are an annual legume and mainly produced for human consumption due to its high protein and energy content; however, there are a considerable amount of peanut crop residue sources for livestock feeding left after harvesting the seeds (Hill, 2002; Pande et al., 2003). Since peanut forage contains a high level of protein, it been used as a ruminant feedstuff (Garduno-Lugo \& Olvera-Novoa, 2008). Besides, Peanut meal is the product that remains after the extraction of oil from peanuts, and it been used as a protein-rich feed source for animal nutrition. Hence peanut straw, the residue of seeds and peanut meal are considered as by-products of peanut production (Feedipedia, 2017).

Peanut seeds contain a high amount of nutrients such as $50 \%$ fatty acids, $25 \%$ protein and $10 \%$ nitrogenfree extract. Average crude protein, nitrogen-free extract and mineral contents of peanut meal are 45, 24 and $5.5 \%$ respectively (Arioglu, 2013). Perennial peanut forage is highly nutritious for beef and dairy cattle, and goats. It was reported in another study that the digestibility of peanut straw produced in Aydın, Turkey was higher in goats than sheep (Sevim, 2013). Khan et al. (2012) showed that peanut straw (Arachis hypogaea L.) might be an excellent alternative forage source for sheep nutrition. Blummel et al. (2005) reported that peanut straw is a -an excellent roughage source for sheep because of its higher organic matter digestibility and protein content. The nutritional quality of perennial peanut appears to be as good as alfalfa for ruminant animals (Hernández-Garay et al., 2004). Recently reported mean $\mathrm{CP}, \mathrm{EE}$, ash and the crude fiber content of peanut straw were $4.93 \%, 0.43 \%, 7.95 \%$ and $17.8 \%$, respectively (Amuridin et al., 2019).

In vitro gas production technique has been widely used to determine organic matter digestibility and to estimate the metabolic energy (ME) of feedstuffs (Menke \& Steingass,1988; Contreras-Govea et al., 2013).

The feeding values of peanut by-products have been affected by environmental factors such as genetic varieties, soil structure, and irrigation. At the time of harvesting large quantities of peanut straw and after oil extraction, peanut meal become available for feeding ruminants, Still, the nutritive values of peanut mostly Virginia variety produced in Osmaniye, Turkey were not well reported. The objective of this study was to evaluate the chemical composition, in vitro digestibility and ME values of the most cultivated variety peanut straw, peanut seed residue and peanut meal in Osmaniye province of Turkey.

\section{MATERIAL AND METHOD}

Animal material: The rumen fluid was collected from slaughtered cattle in Florya Meat Joint-Stock Company, Samsun, Turkey. Beef cattle were fed by grass hay (97 $\mathrm{g} \mathrm{CP} / \mathrm{kgDM} ; 6 \mathrm{MJ} \mathrm{ME} / \mathrm{kg} \mathrm{DM}$ ) ad libitum and 10 $\mathrm{kg}$ of a compound feed twice in a day in the morning and evening time. The compound feed contained $135 \mathrm{~g} \mathrm{CP}, 11$ MJ ME/ kg DM. Ruminal content was directly collected to anaerobically prepared with continuously $\mathrm{CO}_{2}$ flushing into preheated thermos flask at $39{ }^{\circ} \mathrm{C}$. It was transported immediately from Florya slaughterhouse to the Ruminant Feed Evaluation Laboratory of OMU Faculty of Veterinary Medicine Department of Animal Nutrition and Nutritional Diseases. Collected ruminal content was strained through two or three layers of cheesecloth and kept at $39^{\circ} \mathrm{C}$ under a $\mathrm{CO}_{2}$ atmosphere till using for in vitro gas production method.

Feed material: Peanut straw, seed residue and peanut meal samples were collected from Osmaniye province in Turkey. The quadruple samples from collected peanut straw, peanut seed residue and peanut meal were used for each analysis $(n=20)$. Peanut straw, peanut seed residue and peanut meal samples were milled passing through a $1 \mathrm{~mm}$ sieve for chemical and mineral analysis and in vitro gas production method.

Chemical composition analysis: Chemical composition analysis was carried out in the Chemical Analysis Laboratory of OMU Faculty of Veterinary Medicine Department of Animal Nutrition and Nutritional Diseases. OM, CP, EE and ash contents of ground peanut by-product samples were determined according to AOAC methods (AOAC, 2006). CP was calculated as $\mathrm{N} \times 6.25$. $\mathrm{NDF}, \mathrm{ADF}$ and ADL contents of peanut by-products were determined by using ANKOM 200 Fiber Analyzer (ANKOM Technology Corp. Fairport, NY, USA) using the method described by Van Soest et al., (1991). ME $\mathrm{ADF}_{\mathrm{ADF}}$ $(\mathrm{MJ} / \mathrm{kg} \mathrm{DM})$ was estimated by the equation given below (Kirchgessner et al.,1977).

$$
\mathrm{ME}_{\mathrm{ADF}}, \mathrm{MJ} / \mathrm{kg} \mathrm{KM=14.60-0.13x} \mathrm{ADF}
$$

In vitro gas production method: In vitro gas production experiment was carried out in the Ruminant Feed Evaluation Laboratory of Department of Animal Nutrition and Nutritional Diseases, Faculty of Veterinary Medicine, Ondokuz Mayis University. The ANKOM RF gas production system (Ankom RF Gas Production 
System, Ankom Technology, NY, USA) was used for measuring gas production. System parts are an incubator, 12 modules with $250 \mathrm{~mL}$ capacity, and recording computer. The produced gas pressure was recorded at 5 minutes intervals by using ANKOM RF gas production system program.

Approximately $1 \mathrm{~g}$ of ground samples were weighed and put into 12 modules. The prepared artificial salivia (Menke \& Steingass,1988) was mixed with rumen fluid 4:1. A mixture of $100 \mathrm{~mL}$ of this solution was added to a preheated sample containing modules under anaerobic conditions by continuously flushing $\mathrm{CO}_{2}$. Then modules transferred to the incubator at a temperature about $39^{\circ} \mathrm{C}$ and $\mathrm{pH}$ about 6.5 to 6.8 , and in vitro gas production system was started. The average cumulative pressure values were recorded at $0,3,6,12,24,48,72$ and 96 hours, and these values were converted to $\mathrm{mL}$ of gas at standard temperature and pressure.

OMD \%, $\mathrm{ME}_{\mathrm{GP}}$, and $\mathrm{ME}_{\mathrm{OMD}}(\mathrm{MJ} / \mathrm{kg} \mathrm{DM})$ values of samples were estimated from gas measured by in vitro method at $24 \mathrm{~h}$ by using the below equations (Menke \& Steingass, 1988).

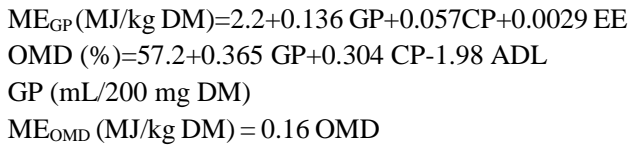

Statistical analysis: One-Way analysis of variance and multiple comparisons among DM, Ash, OM, $\mathrm{CP}, \mathrm{EE}, \mathrm{NDF}, \mathrm{ADF}, \mathrm{ADL}, \mathrm{GP}, \mathrm{OMD}$ and ME values of peanut straw, peanut seed residue and peanut meal means were performed by Duncan's new multiple ranges (SAS, 2007). Means differences were considered significant at $\mathrm{P}<0.01$

\section{RESULTS AND DISCUSSION}

Chemical composition of peanut straw, peanut seed residue and peanut meal is shown in Table 1 . The CP content was found to be $10.22,23.16$ and $41.25 \%$ of peanut straw, peanut seed residue and peanut meal, respectively. Statistically significant differences were found between the $\mathrm{CP}$ mean values of peanut straw, peanut seed residue and peanut meal $(\mathrm{P}<0.01)$. The mean $\mathrm{CP}$ level of peanut straw (\%) was quite higher then previously reported mean CP (4.93\%), however. ash contents were similar to each other (Amuridin et al., 2019). As the protein value of the feedstuff increases, the value of the feedstuff is considered as high-quality feed. However, bacteria in the rumen have been reported to need at least 10 $\%$ protein - to perform microbial activities (Norton, 2016). In the present study, any of the peanut by-products investigated contains more than $10 \% \mathrm{CP}$. The obtained mean $\mathrm{CP}$ levels of peanut straw were similar to previously reported values for peanut $\mathrm{NC}-7$ variety straw (Ozyigit \& Bilgen, 2013). The mean CP levels of peanut meals collected from 17 different peanut oil extracting factories were given as $45.6 \pm 2.8 \%$ in the range of $40.1 \%-50.9 \%$ (Batal et al., 2005). Since peanut seed residues contain high $\mathrm{CP}$, it may be used as a good source for animal nutrition.

Table 1. Chemical composition of peanut straw, peanut seed residue and peanut meal (mean $\pm S E, n=20$.

\begin{tabular}{lccc}
\hline Crude nutritive values (\%) & Peanut straw & Peanut seed residue & Peanut meal \\
\hline DM & $93.01 \pm 0.15$ & $91.8 \pm 0.23$ & $92.28 \pm 0.21$ \\
Ash & $7.90^{\mathrm{b}} \pm 0.09$ & $10.78^{\mathrm{a}} \pm 0.11$ & $6.3^{\mathrm{c}} \pm 0.05$ \\
OM & $92.1^{\mathrm{b}^{\mathrm{b}} \pm 0.08}$ & $89.22^{\mathrm{c}} \pm 0.15$ & $93.70^{\mathrm{a}} \pm 0.10$ \\
$\mathrm{CP}$ & $10.22^{\mathrm{c}} \pm 0.14$ & $23.16^{\mathrm{b}} \pm 0.12$ & $41.15^{\mathrm{a}} \pm 0.13$ \\
$\mathrm{EE}$ & $2.30^{\mathrm{c}} \pm 0.08$ & $8.21^{\mathrm{a}} \pm 0.04$ & $6.45^{\mathrm{b}} \pm 0.09$ \\
$\mathrm{NDF}$ & $51.14^{\mathrm{a}} \pm 0.10$ & $35.27^{\mathrm{b}} \pm 0.08$ & $28.44^{\mathrm{c}} \pm 0.10$ \\
ADF & $41.72^{\mathrm{a}} \pm 0.08$ & $18.83^{\mathrm{b}} \pm 0.09$ & $13.20^{\mathrm{c}} \pm 0.12$ \\
ADL & $8.77^{\mathrm{a}} \pm 0.11$ & $6.17^{\mathrm{b}} \pm 0.13$ & $4.71^{\mathrm{c}} \pm 0.14$ \\
ME, MJ/kg DM & $9.18^{\mathrm{b}} \pm 0.04$ & $9.38^{\mathrm{b}} \pm 0.03$ & $12.88^{\mathrm{a}} \pm 0.05$ \\
\hline a,b,c, Row means with different superscripts differ significantly at P< $0.01 \mathrm{DM}$ : Dry Matter, OM: \\
Organic Matter, CP: Crude Protein, EE: Ether Extract, NDF: Neutral Detergent Fiber, ADF: Acid \\
Detergent Fiber, ADL: Acid Detergent Lignin, ME: Metabolic Energy, n: Number of samples.
\end{tabular}

The determining crude oil or EE values of peanut straw, peanut seed residue and peanut meal were 2.30, 8.21 and $6.45 \%$, respectively. The differences between the mean values of peanut by-products were significantly different $(\mathrm{P}<0.01)$. The estimated mean EE value of peanut meal was higher than the values reported by Heuze et al., (2016). This situation may be due to the different techniques used for seed processing in oil production factories. Necessary attention has to be paid when the high fat containing feedstuffs like peanut seed residue was used in ruminant animals diet because they may suppress rumen cellulolytic bacteria and cause impairment on digestibility of plant cell wall components (Van Soest, 1994). Fieroni et al. (2015) showed that palm oil diet impaired ruminal function parameters without contributing effectively in providing unsaturated fatty acid into the duodenum of beef cattle.

The obtained mean ash levels of peanut straw, peanut seed residue and peanut meal were 7.90, 10.78 and $6.30 \%$ consecutively. Differences between mean values of peanut by-products were significant $(\mathrm{P}<0.01)$. Ash $\%$ values of peanut production by products are consistent with the values reported by Etela et al., (2011). It has been shown that the by-products of peanut Osmaniye Virginia variety production can be used as animal feedstuffs in terms of ash content of straw, peanut seed residue and peanut meal.

In our study, the obtained mean NDF, ADF and ADL levels of peanut straw, peanut seed residue and peanut meal were $51.14,35.27$ and $28.44 \%$; 41.72, 18.83 and $13.20 \% ; 8.77,6.17$ and $4.71 \%$, respectively. Differences between NDF, ADF and ADL mean values of peanut by-products were significant $(\mathrm{P}<0.01)$. The 
components of the cell wall found in the structures of plant originated feed especially lignin, determine the digestibility of feedstuffs (Van Soest, 1994). Feed intake is directly related toits NDF content. However, ADF content of feeds determines their digestibilities. The estimated $\mathrm{NDF}, \mathrm{ADF}$ and ADL mean values of peanut by-products were found similar to values previously reported and summarized in Feedipedia (2017). ME $\mathrm{ADF}_{\mathrm{A}}$ contents of peanut by-products were $9.18,9.38$ and $12.88 \mathrm{MJ} / \mathrm{kg} \mathrm{DM}$, consecutively. The highest $\mathrm{ME}_{\mathrm{ADF}}$ value was determined for peanut meal. Differences in mean values were significantly important for peanut by-products $(\mathrm{P}<0.01)$.

The cumulative Ppsi, cumulative GP $\mathrm{mL}$, OMD $\%$, MEOMD (MJ/kg DM) and MEGP (MJ/kgDM values of peanut straw, peanut seed residue and peanut meal estimated by using of in vitro gas production method is presented in Table 2. Mean Ppsi, cumulative GP ml/200 mg DM, OMD \%, $\mathrm{ME}_{\mathrm{OMD}}(\mathrm{MJ} / \mathrm{kg} \mathrm{DM})$ and $\mathrm{ME}_{\mathrm{GP}}(\mathrm{MJ} / \mathrm{kg}$ $\mathrm{DM})$ were $14.58,10.36$ and $12.63 \mathrm{Psi} ; 36.12,25.66$ and $31.29 \mathrm{~mL} ; 56.12,61.38$ and $71.80 \%$; 8.98, 9.82 and 11.49 $\mathrm{MJ} / \mathrm{kg} \mathrm{DM} ; 7.69,7.03$ and $8.81 \mathrm{MJ} / \mathrm{kg} \mathrm{DM}$, respectively. There were statistically significant differences between of peanut by-products in vitro gas production parameters $(\mathrm{P}<0.01)$. The major causes of the differences in gas production, OMD and ME values of peanut by-products because of the substantial differences in the estimated amount of $\mathrm{CP}, \mathrm{EE}, \mathrm{NDF}, \mathrm{ADF}$ and ADL levels of peanut by-products. The estimated mean OMD and ME values of peanut Osmaniye Virginia straw, seed residue and meal were in the range of previously reported levels (Batal et al., 2005; Feedipedia, 2017).

Table 2. Cumulative gas production volume at $24 \mathrm{~h}\left(\mathrm{P}_{\mathrm{psi}}\right.$ and $\mathrm{GP}_{\mathrm{mL}}$ ), organic matter digestibility (OMD) and metabolic energy (MEOMD and $\mathrm{ME}_{\mathrm{GP}}$ ) values of peanut straw, peanut seed residue and peanut meal (mean $\pm \mathrm{SE}, \mathrm{n}=20$ ).

\begin{tabular}{lccc}
\hline Gas production parameters & Peanut straw & Peanut seed residue & Peanut meal \\
\hline $\mathrm{P}_{\mathrm{psi}}$ & $14.58^{\mathrm{a}} \pm 0.15$ & $10.36^{\mathrm{c}} \pm 0.17$ & $12.63^{\mathrm{b}} \pm 0.13$ \\
$\mathrm{GP} \mathrm{P}_{\mathrm{mL}}$ & $36.12^{\mathrm{a}} \pm 0.21$ & $25.66^{\mathrm{c}} \pm 0.22$ & $31.29^{\mathrm{b}} \pm 0.29$ \\
$\mathrm{OMD} \%$ & $56.12^{\mathrm{c}} \pm 0.09$ & $61.38^{\mathrm{b}} \pm 0.13$ & $71.80^{\mathrm{a}} \pm 0.16$ \\
$\mathrm{MEOMD}(\mathrm{MJ} / \mathrm{kgDM})$ & $8.98^{\mathrm{c}} \pm 0.05$ & $9.82^{\mathrm{b}} \pm 0.04$ & $11.49^{\mathrm{a}} \pm 0.06$ \\
$\mathrm{ME}_{\mathrm{GP}}(\mathrm{MJ} / \mathrm{kgDM})$ & $7.69^{\mathrm{b}} \pm 0.10$ & $7.03^{\mathrm{c}} \pm 0.09$ & $8.81^{\mathrm{a}} \pm 0.14$ \\
\hline a,b,c, Row means with different superscripts differ significantly at $\mathrm{P}<0.01$. n:Number of samples.
\end{tabular}

\section{CONCLUSION}

In conclusion, the estimated nutrients, organic matter digestibility and metabolic energy of peanut Osmaniye Virginia variety straw, seed residue and meal show that these by-products may be used as a nutrient-rich feedstuff for ruminant animal nutrition.

\section{ACKNOWLEDGEMENTS}

The authors would like to thank Ondokuz Mayis University for providing research facilities and funding (Project number: OMU. PYO.VET.1901.16.010). The authors also thank to DVM Ozkan Sahin for peanut straw, peanut seed residue and peanut meal sample collection from Osmaniye, Turkey.

\section{REFERENCES}

Amirudin, Amar, A.L., Thaha, A. \& Lapandjang, I. (2019). Combination ration made of corn straw, peanut straw, gliricidia leaves and napier grass on beef cattle. Plant Archives, 19(2), 835-838.

AOAC. (2006). Official Methods of Analysis, 18th ed., Association of Official Analytical Chemists, Inc., Arlington, VA, USA.

Arioglu, H. (2013). Peanut Production. Cukurova University. Faculty of Agriculture, Report of Department of Plant Production. Adana, Turkey.

Batal, A., Dale, N. \& Cafe, M. (2005). Nutrient composition of peanut meal. Journal of Applied Poultry Research, 14, 254-257.

Blummel, M., Vellaikumar, S., Devulapalli, R., Nigam, S. N., Upadhyaya, H.D. \& Khan, A. (2005). Preliminary observations on livestock productivity in sheep fed exclusively on haulms from eleven cultivars of groundnut. International Arachis Newsletter, 25, 55-57.

Contreras-Govea, F.E., Muck, R.E., Broderick, G.A. \& Weimer, P.J. (2013). Lactobacillus plantarum effects on silage fermentation and in vitro microbial yield. Animal Feed Science Technology, 179, 61-68. DOI: 10.1016/j.anifeedsci.2012.11.008.

Etela, I. \& Dung, D.D. (2011). Utilization of stover from six improved dual-purpose groundnuts (Arachis hypogaea L.) cultivars by West African Dwarf Sheep. African Journal Food Agriculture, Nutrition and Development, 11(1), 4538-4545.

Feedipedia. (2017). Animal Feed Resources Information System INRA CIRAD AFZ and FAO C 20122016. http://www.feedipedia.org/node /12167. (25 Şubat 2020).

Fiorentini, G., Carvalho, I.P.C., Messana, J.D., Canesin, R.C., Castagnino, P.S., Lage, J.F., Arcuri, P.B. \& Berchielli, T.T. (2015). Effect of lipid sources with different fatty acid profiles on intake, nutrient digestion and ruminal fermentation of feedlot nellore steers. AsianAustralas Journal Animal Science, 28(11), 15831591.

Garduno-Lugo, M. \& Olvera-Novoa, M.A. (2008). Potential of the use of peanut (Arachis hypogaea) leaf meal as a partial replacement for fish meal in diets for Nile tilapia (Oreochromis niloticus L.). Aquaculture Research. 39, 1299-1306. DOI: 10.1111/j.1365-2109.2008.01995.x.

Hernández-Garay, A., Sollenberger, L.E., Staples, C.R. \& Pedreira, C.G.S. (2004). Florigraze and Arbrook rhizoma peanut as pasture for growing Holstein heifers. Crop Science, 44, 1355-1360.

Heuzé, V., Thiollet, H., Tran, G., Bastianelli, D. \& Lebas, F. (2016). Peanut meal. Feedipedia, a 
programme by INRA, CIRAD, AFZ and FAO. http://www.feedipedia.org/node/699 Last updated on October 4, 2016, 10: 25

Hill, G.M. (2002). Peanut by-products fed to cattle. The Veterinary Clinics of North America, Food Animal Practices, 18(2), 295-315. DOI: 10.1016/S0749-0720(02)00019-1.

Kirchgessener, M., Kellner, R.J., Roth, F.X. (1977). Zur Schatzung des futterwertes mittels rohfaser und der Zellwandfraktionen der detergentien-analyse. Landwirtsch. Forsch, 30, 245-250.

Khan, M.T., Khan, N.A., Bezabih, M., Qureshi, M.S. \& Rahman, A. (2012). The nutritional value of peanut hay (Arachis hypogaea L.) as an alternate forage source for sheep. Tropical Animal Health and Production, 45, 849-853.

Menke, K.H. \& Steingass, H. (1988). Estimation of the energetic feed value obtained from chemical analysis and in vitro gas production using rumen fluid. Animal Research Development Separate Print, 28, 7-55.

Norton, B.W. (2016). The nutritive value of tree legumes. http://www.fao.org/ag/AGP/AGPC/doc/Pubicat/ Gutt-shel/x5556e0j.htm. pp. 1-10. (20.02.2020).

Ozyigit, Y. \& Bilgen, M. (2013). Forage potential of some groundnuts (Arachis hypogaea L.) cultivars. Romanian Agriculture Research, 30, 57-63.

Pande, S., Bandyopadhyay, R., Blummel, M., Narayana, Rao J., Thomas, D. \& Navi, S.S. (2003). Disease management factors influencing yield and quality of sorghum and groundnut crop residues. Field Crops Research, 84, 89-103. DOI: 10.1016/S0378-4290(03)00143-6.

Sevim, O. (2013). Influence of slow-release nitrogen and different source of non-structural carbohydrates supplementation to groundnut straw on digestibility and some rumen parameters in sheep and goats. Adnan Menderes University Faculty of Veterinary Medicine. Animal Nutrition and Nutritional Diseases. Ph.D. Thesis, Aydın, Turkey.

Stalker, T. \& Wilson, R.F. (2015). Peanuts: Genetics, Processing, and Utilization, Editör: Thomas Stalker and Richard F. Wilson. Academic Press and AOCS Press, Published by Elsevier Inc. ISBN 1630670391, 9781630670399. pp 498.

SAS. (2007). SAS statistic software, SAS campus drive. Cary NC, USA.

TUIK. (2019). http://www.tuik.gov.tr/PreTablo.do? alt_id=1001. (25 Şubat 2020)

Van Soest, P.J., Robertson, J.D. \& Lewis, B.A. (1991). Methods for dietary fiber, neutral detergent fiber and non-starch polysaccharides in relation to animal nutrition. Journal of Dairy Science. 74, 3583-3597. DOI: $\quad 10.3168 /$ jds.SO0220302(91)78551-2.

Van Soest, P.J. (1994). Nutritional ecology of the ruminant. 2. ed. Ithaca: Cornell University Press, $476 \mathrm{p}$. 